\title{
Manajemen Pemeliharaan Bangunan Gedung Sekolah (Studi Kasus Gedung SLTA di Balikpapan)
}

\author{
Mahfud, S.Pd. MT \\ Jurusan Teknik Sipil \\ Politeknik Negeri Balikpapan \\ J1. Soekarno Hatta Km.8 Balikpapan \\ Email : mahfud@poltekba.ac.id
}

\begin{abstract}
Everything naturally made by human was subjected to damage. The length of utility, however, could be increased through periodic improvement with the activity known as maintenance. The maintenance was a combination of several activities to preserve an asset or to improve it to a certain condition that acceptable to the standard determined by the company that conducting the maintenance.

Research was aimed at understanding the effect of the maintenance of architecture component, structure component, and utility component on the quality of the maintenance of SLTA building in Balikpapan. Data analysis employs descriptive analysis and path analysis.

Results of research, simultaneously, indicated that the strong effect rate was $97.73 \%$ with independent variable coefficient of 0.324 for $X_{1}$ (architecture component), 0.197 for $X_{2}$ (structure component), and 0.456 for $X_{3}$ (utility component). The probability rate of significance of $0.03<0.05$ had been concluded as that the maintenance of architecture, structure and utility components could have significant effect on the quality of building maintenance. If the maintenance of $X_{1}, X_{2}$ and $X_{3}$ could be improved, the quality of the maintenance of SLTA building in Balikpapan might be ensured.
\end{abstract}

Keywords: school building, Balikpapan, the quality of the maintenance, path analysis

\begin{abstract}
Abstrak
Secara alamiah tidak ada benda yang dibuat oleh manusia yang tidak bisa rusak, tetapi usia kegunaannya dapat diperpanjang dengan melakukan perbaikan secara berkala melalui aktivitas yang dikenal sebagai pemeliharaan. Pemeliharaan adalah suatu kombinasi dari berbagai tindakan yang dilakukan untuk menjaga suatu aset, atau memperbaikinya sampai pada suatu kondisi yang bisa diterima dengan merujuk pada standar yang ditentukan oleh organisasi yang melakukan pemeliharaan.

Penelitian ini dimaksudkan untuk mengetahui pengaruh pemeliharaan komponen arsitektur, komponen struktur, dan komponen utilitas terhadap kualitas pemeliharaan bangunan gedung SLTA di Balikpapan, analisis data menggunakan analisis deskriptif dan analisis jalur (path analysis)

Hasil penelitian, secara simultan menunjukkan tingkat pengaruh yang sangat kuat juga yaitu sebesar $97.73 \%$ dengan koefisien variabel bebas $.0 .324 X_{1}$ (komponen arsitektur), $0.197 X_{2}$ (komponen struktur), dan 0.456 $X_{3}$ (komponen utilitas). Dengan nilai Probabilitas sig $0.03<0.05$ maka dapat disimpulkan bahwa pemeliharaan komponen arsitektur, struktur, utilitas berpengaruh secara signifikan terhadap kualitas pemeliharaan bangunan gedung. Sehingga apabila pemeliharaan $X_{1}, X_{2}$, dan $X_{3}$ di tingkatkan, maka akan meningkatkan kualitas pemeliharaan bangunan gedung SLTA di Balikpapan.
\end{abstract}

Kata Kunci: gedung sekolah, Balikpapan, kualitas pemeliharaan, analisis jalur.

\section{Pendahuluan}

Secara alamiah tidak ada benda yang dibuat oleh manusia yang tidak bisa rusak, tetapi usia kegunaannya dapat diperpanjang dengan melakukan perbaikan secara berkala melalui aktivitas yang dikenal sebagai pemeliharaan. Pemeliharaan adalah suatu kombinasi dari berbagai tindakan yang dilakukan untuk menjaga suatu aset, atau memperbaikinya sampai pada suatu kondisi 
yang bisa diterima dengan merujuk pada standar yang ditentukan oleh organisasi yang melakukan pemeliharaan. Hal ini penting terutama bagi negara berkembang karena kurangnya sumber daya modal untuk penggan-tian aset di maksud (Corder, 1996).

Seiring dengan berjalannya waktu, terjadi banyak perubahan, baik secara fisik maupun finansial pada bangunan gedung yang sudah jadi. Oleh karena itu, perlu adanya perhatian yang lebih terhadap bangunan tersebut. Hal ini dapat diwujudkan dengan dilakukannya kegiatan peme-liharaan bangunan gedung. Namun seringkali kegiatan pemeliharaan ini hanya dilakukan bila terdapat masalah pada bangunan tersebut saja. Terbatasnya dana merupakan salah satu penyebab dimana kegiatan pemeliharaan ini seringkali dilupakan. Maka, perlu ditekankan kepada pengelola bangunan agar kegiatan peme-liharaan dilakukan secara sistematis.

Kegiatan pemeliharaan gedung di maksudkan untuk menjaga dan memperta hankan kondisi bangunan beserta elemen dan peralatan yang digunakan di gedung tersebut agar dapat berfungsi sesuai rencana serta menjaga terhadap pengaruh yang merusak sehingga mencapai ataupun melebihi umur rencana yang telah ditentukan dan akan memberikan nilai lebih berkaitan dengan kualitas gedung dan juga keamanan bagi pengguna.

Perlu ditekankan pula, dengan dilakukannya kegiatan pemeliharaan secara berkala akan mengurangi risiko pengeluaran biaya akibat kerusakan gedung dikemudian hari. Gedung yang dipelihara dengan baik dan benar juga akan meningkatkan mutu dari lingkungan hidup, baik di dalam maupun di luar gedung, dengan kata lain pemeliharaan gedung yang baik akan memberikan perasaan nyaman, aman, tenang dan bersih kepada masing-masing individu sehingga dapat meningkatkan produktivitas kerja.

Pepatah mengatakan, "membangun me-rupakan pekerjaan yang jauh lebih mudah di bandingkan dengan upaya mempertahankan hasil pembangunan tersebut". Terutama dalam bidang konstruksi, dari perumahan, jembatan, jalan maupun gedung, di Indonesia dapat dilihat bah-wa pepatah tersebut seringkali tepat. Tidaklah heran gedung yang mulanya indah dan megah, akan rusak hanya dalam beberapa tahun saja, dan ironisnya gedung tersebut sampai roboh hingga mengakibatkan melayangnya jiwa manusia. Seperti kejadian robohnya gedung sekolah yang terjadi belakangan ini, sebagai berikut:

Tabel 1: Data Kerusakan Gedung Sekolah

\begin{tabular}{|c|c|c|c|}
\hline NO & NAMA SEKOLAH & MUSIBAH & $\begin{array}{l}\text { KORBAN } \\
\text { JIWA }\end{array}$ \\
\hline 1 & SDN 3 Karang Lampung & Gedung roboh & $\begin{array}{l}1 \text { siswa } \\
\text { meninggal }\end{array}$ \\
\hline 2 & SMP Al-Muhlishin & Atap runtuh & $\begin{array}{l}2 \text { siswa luka } \\
\text { berat }\end{array}$ \\
\hline 3 & SMP Negeri 6 Blitar & Gedung roboh & $\begin{array}{l}3 \text { siswa luka } \\
\text { berat }\end{array}$ \\
\hline 4 & SDN 2 Sambeng Blora & Gedung roboh & $\begin{array}{l}1 \text { guru luka } \\
\text { berat }\end{array}$ \\
\hline 5 & SMU Negeri 7 Bogor & Gedung roboh & 30 siswa luka \\
\hline 6 & SMP Purnama Jateng & Gedung roboh & $\begin{array}{l}5 \text { siswa luka- } \\
\text { luka }\end{array}$ \\
\hline 7 & SD Negeri 10 Serang & Gedung roboh & - \\
\hline 8 & SDN Gading 2 Sumenep & Gedung roboh & - \\
\hline 9 & $\begin{array}{l}\text { SD Negeri Setia Bakti } \\
\text { Tangerang }\end{array}$ & $\begin{array}{l}\text { Gedung } \\
\text { Roboh }\end{array}$ & - \\
\hline 10 & SDN Clarak Probolinggo & Gedung roboh & - \\
\hline 11 & SDN Sidomoro 1 Gresik & Gedung roboh & $\begin{array}{l}10 \text { siswa luka } \\
\text { berat }\end{array}$ \\
\hline 12 & SD Negeri Karawaci 3 & Plafon runtuh & 16 siswa luka \\
\hline 13 & SMP Negeri 5 Medan & Atap runtuh & $\begin{array}{l}7 \text { siswa luka } \\
\text { berat }\end{array}$ \\
\hline 14 & SD Muh XI Solo & Atap runtuh & $\begin{array}{l}3 \text { siswa luka } \\
\text { berat }\end{array}$ \\
\hline 15 & SMU Pluit Raya & Atap runtuh & $\begin{array}{l}3 \text { siswa luka- } \\
\text { luka }\end{array}$ \\
\hline 16 & SDN Mentaos Jombang & Gedung roboh & - \\
\hline 17 & SMP Negeri 1 Bekasi & Gedung roboh & - \\
\hline 18 & SDN 21 Kramat Jati & Atap runtuh & - \\
\hline 19 & $\begin{array}{l}\text { SD Negeri Krangkeng } 1 \\
\text { Indramayu }\end{array}$ & Gedung roboh & $\begin{array}{l}1 \text { siswa luka } \\
\text { berat }\end{array}$ \\
\hline 20 & SD Pasundan 3 Ciparay & Atap runtuh & - \\
\hline
\end{tabular}

Sumber: www.kompas.com, www.mediaindonesia.com, www.tempointeraktif.com.

Selain data tersebut di atas, informasi dari beberapa daerah di Indonesia menyebutkan diantaranya 969 gedung sekolah di Kabupaten Magelang rusak berat (Kepala Dinas Pendidikan Kabupaten Magelang dalam www.kompas.com), $70 \%$ gedung sekolah di 
DKI rusak (Kepala Pendidikan Dasar DKI dalam www.media indonesia.com), $50 \%$ atau 720 gedung sekolah di Garut masih rusak (Kepala Bidang Sekolah Dinas Pendidikan Kabupaten Garut dalam www. republika.co.id), $30 \%$ atau 400 gedung sekolah di Cianjur rusak berat (Bupati Cianjur dalam www.republika.co.id), $28.83 \%$ atau 322 gedung Sekolah Dasar di Malang mengalami kerusakan (Kepala Pendidikan Dasar, Dinas Pendidikan Kota Malang dalam www.tempointeraktif.com)

Dari data di atas, menunjukkan bahwa sebagaian besar pemeliharaan dan perawatan gedung sekolah yang di lakukan pemerintah dan pengelola sekolah masih perlu ditingkatkan.

Sistem operasi dan pemeliharaan untuk infrastruktur berkembang perlahan. Aset-aset da- lam sektor publik termasuk bangunan pendi-dikan tidak mendapat penelitian sama dari yang seharusnya bila infrastruktur tersebut menjadi subyek untuk kompetisi pasar. Tidak efisiennya alokasi investasi mengakibatkan maasalah yang tidak berguna dan pada akhirnya memerlukan investasi yang besar untuk perbaikan. Oleh karena itu teknologi yang terkini dan metode menejemen pemeliharaan aset efektif sangat di butuhkan. (Siregar D. Doli, 2004).

Indonesia dibanding 11 negara lain di kawasan asia yaitu Cina, Filipina, Hongkong, Jepang, Korea Selatan, Malaysia, Singapura, Thailand, Taiwan, dan Vietnam, rating kualitas infrastruktur Indonesia terendah alias berada pada urutan 12 (Kodoatie, 2005). Selain rendah- nya kualitas infrastruktur tersebut, juga rendah pula kualitas manajemen pemeliharaan yang disediakan, sehingga kualitas layanan dan fungsi infrastruktur tersebut menurun secara cepat dan sangat signifikan. Sistem dan manajemen pemeliharaan ini sangat perlu mendapat perhatian baik dari pihak pemerintah, swasta, dan masyarakat agar fungsi dan peranan aset tersebut tidak hilang, seiring dengan kebutuhan masyarakat akan hadirnya fasilitas publik tersebut yaitu sistem fisik yang menyediakan transportasi, pengairan, drainase, bangunan gedung dan fasili-tas publik lainnya yang dibutuhkan untuk memenuhi kebutuhan dasar manusia dalam lingkup sosial dan ekonomi (Kodoatie, 2005)

Bangunan gedung sebagai tempat manu-sia melakukan kegiatan, mempunyai peranan yang sangat strategis dalam pembentukan watak, perwujudan kreativitas, dan jati diri manusia sekaligus untuk mewujudkan dan mempertahan-kan gedung yang handal, berjati diri, serta seimbang, serasi, dan selaras dengan lingkungan.

Dengan dipenuhinya persyaratan teknis bangunan gedung sesuai dengan fungsi dan klasifikasinya serta telah bersertifikat laik fungsi bangunan gedung, maka diharapkan kegagalan konstruksi maupun kegagalan bangunan gedung itu sendiri dapat dihindari, sehingga pengguna bangunan gedung dapat hidup lebih tenang dan sehat.

Dari uraian pada latar belakang, dapat ditarik kesimpulan beberapa hal yang menjadikan kurangnya perhatian terhadap pemeliharaan bangunan antara lain: 1) Citra masyarakat dan pengelola gedung terhadap pemeliharaan dan perbaikan bangunan masih rendah bila diban-dingkan dengan citra pembangunan, sehingga pembangunan baru di anggap lebih penting. 2) Kurangnya minat dan perhatian dari lingkungan akademisi untuk mengkaji dan meneliti masalah terkait dengan pemeliharaan bangunan, yang menyebabkan publikasi dan teknologi yang di pergunakan juga ketinggalan bila dibandingkan dengan teknologi dalam pembangunan gedung. 3) Belum adanya strategi dan kebijaksanaan yang jelas perihal pengawasan dalam pemeliharaan bangunan gedung oleh pihak pembuat regulasi padahal bangunan gedung merupakan aset negara berupa investasi bangunan yang bernilai trilyunan rupiah. 4) Lemahnya pembinaan penca-tatan mengenai informasi tentang gedung, seperti : as built drawing, dokumen gedung mengenai kapan, bagimana, berapa biaya pemeliharaan yang pernah dilakukan. Hal ini menyebabkan tidak adanya informasi pendukung yang mema-dai 
untuk penyusunan strategi pemeliharaan di kemudian hari. 5) Pemeliharan bangunan masih dianggap sebagai komplemen bangunan dan semata-mata masih merupakan permasalahan teknis. Sehingga pemeliharaan bangunan belum merupakan bagian integral dari tujuan dan fungsi organisasi yang menggunakan gedung tersebut.

Berdasarkan uraian pada latar belakang di atas, maka permasalahan dalam penelitian ini dapat dirumuskan sebagai berikut: 1) Bagaima-nakah program pemeliharaan bangunan gedung SLTA di Kota Balikpapan didasarkan pada kondisi saat ini. 2) Diantara komponen arsitektur, komponen struktur dan komponen utilitas, secara parsial komponen mana yang paling berpengaruh terhadap kualitas pemeliharaan bangunan gedung guna mempertahankan usia pakai bangunan gedung SLTA di Kota Balikpapan. 3) Bagaima-nakah pengaruh pemeliharaan komponen arsitektur, komponen struktur dan komponen utilitas secara simultan terhadap kualitas peme-liharaan bangunan gedung guna memperta-hankan usia pakai bangunan gedung SLTA di Kota Balikpapan.

Tujuan dari penelitian ini adalah: 1) Untuk mengetahui manajemen pemeliharaan bangunan gedung SLTA di Kota Balikpapan disesuaikan dengan kondisi saat ini. 2) Untuk mengetahui komponen pemeliharan bangunan gedung yang paling berpengaruh secara parsial terhadap kualitas pemeliharaan gedung guna memper-tahankan usia pakai bangunan gedung SLTA di Kota Balikpapan. 3) Untuk mengetahui pengaruh pemeliharaan komponen arsitektur, komponen struktur dan komponen utilitas secara simultan terhadap kualitas pemeliharaan guna memper-tahankan usia pakai bangunan gedung SLTA di Kota Balikpapan.

Untuk membatasi analisis penelitian terhadap permasalahan yang ada, maka dilaku-kan pembatasan masalah yaitu: 1) Penelitian ini dilakukan terbatas pada persepsi pihak pengelola dan pihak pengguna bangunan gedung SLTA Negeri di Kota Balikpapan. 2) Responden yang dipilih adalah sekolah (lembaga pendidikan) SLTA Negeri se Balikpapan, dimana anggaran pemeliharaan bangunan gedungnya merupakan tanggung jawab pemerintah. 3) Prediksi risiko atas kegagalan struktur akibat kualitas bangunan gedung tidak dilakukan dalam variabel dan indikator penelitian ini dan lebih ditekankan atas pengamatan secara visual dari responden. 4) Penelitian ini dilakukan terbatas pada variabel dan indikator yang diajukan peneliti dalam kuisioner.

Keputusan Menteri Pemukiman dan Prasarana Wilayah Nomor 332 Tahun 2002: 1) Pemeli-haraan bangunan adalah usaha untuk memper-tahankan kondisi bangunan agar tetap berfungsi sebagaimana mestinya atau dalam usaha mening-katkan wujud bangunan, serta menjaga terhadap pengaruh yang dapat merusak. 2) Pemeliharaan bangunan juga merupakan upaya untuk meng-hindari kerusakan komponen gedung akibat keusangan sebelum umurnya berakhir. 3) Besarnya biaya pemeliharaan bangunan gedung tergantung pada fungsi dan klasifikasi bangunan. Menurut Btitish Standar (3811:1976), di jelaskan pekerjaan pemeliharaan terbagi atas 2 yaitu: 1) Pemeliharaan Terencana (planned maintenance). Adalah pemeliharaan yang diorganisasi dan dilakukan untuk pemikiran di masa yang akan datang serta pencatatan, yang meliputi: a) Pemeliharaan pencegahan yaitu pemeriksaan yang berdasar pada lihat, rasakan, dengarkan dan penyetelan minor pada selang waktu yang telah ditentukan serta penggantian komponen minor yang ditemukan perlu diganti pada saat pemeriksaan. b) Pemeliharaan korektif yaitu pemeli-haraan yang meliputi reparasi minor, terutama untuk rencana jangka pendek yang mungkin timbul di antaranya yaitu melakukan pemeri-ksaan, juga perbaikan total yakni suatu perluasan yang direncanakan dalam rincian untuk jangka panjang sebagai hasil pemeriksaaan pencegah-an. 2) Pemeliharaan 
Tak Terencana (unplanned maintenance). Yaitu pemeliharaan darurat sebagai pemeliharaan di mana perlu dengan segera di laksanakan tindakan untuk mencegah akibat yang lebih serius, misal nya kerusakan besar pada komponen atau peralatan atau untuk alasan keselamatan kerja. (gambar 1).

Tujuan dari pemeliharaan bangunan ge-dung adalah untuk menjaga keandalan bangunan gedung. Undang-Undang Republik
Indonesia Nomor 28 Tahun 2002 tentang bangunan ge-dung, meliputi: 1) Keselamatan: Struktur Bangunan Gedung, Pengamanan terhadap bahaya kebakaran, Jalur penyelamatan, Sistem penangkal petir, Instalasi listrik, Instalasi gas pembakaran. 2) Kesehatan: Ventilasi dan pengkondisian udara, cahaya, sanitasi dan bahan bangunan.

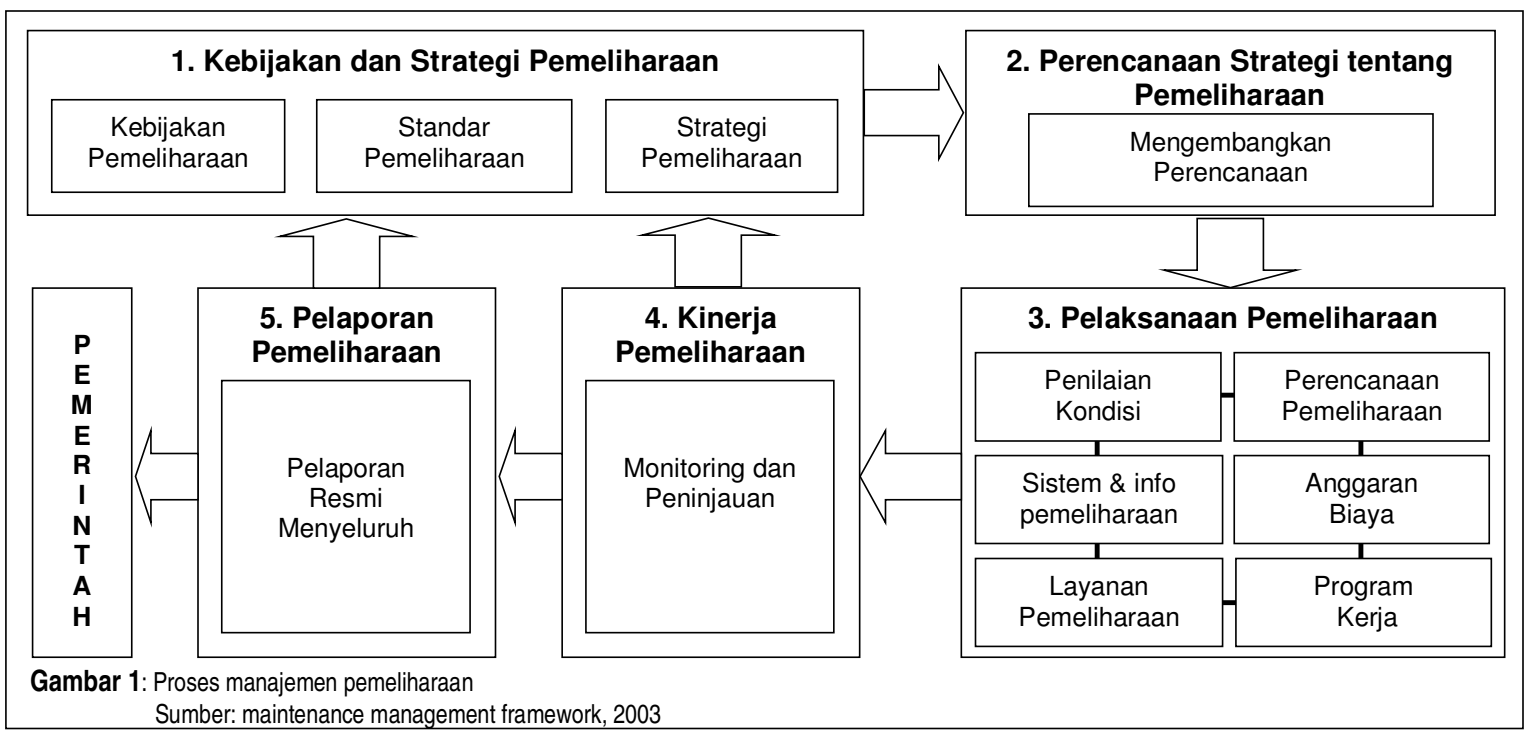

3) Kenyamanan: Kenyamanan ruang gerak dan hubungan antar ruang, Kondisi udara dalam ruang, Pandangan, Tingkat getaran, Tingkat kebisingan. 4) Kemudahan: Kemudahan hubungan ke, dari dan di dalam bangunan ge-dung, Kelengkapan prasarana dalam peman-faatan bangunan gedung. Sedangkan Antony Corder, 1996. menyebutkan tujuan dari pemeli-haraan gedung adalah: Untuk memperpanjang usia kegunaan aset yang setiap bagian dari suatu tempat kerja, bangunan dan isinya. Hal ini terutama penting di negara berkembang karena kurangnya sumber daya. Lingkup pemeliharaan bangunan gedung (Permen PU Nomor 24 Tahun 2008), adalah: Arsitektural, Struktural, Meka-nikal, Elektrikal, Tata Ruang Luar, Tata Grha (housekeeping). Pedoman Pemeliharaan dan Perawatan
Bangunan Gedung, menjelaskan struktur organisasi pemeliharaan dan perawatan bangun-an gedung adalah sebagai berikut: 1) Manajer Bangunan (building manager). Meng-koordinir pekerjaan Kepala Departemen Teknik (chief engineering), Kepala Departemen Tata Grha (chief housekeeping), Kepala Departemen Administrasi \& Keuangan, dan Layanan Pelanggan (chief finance \& administration dan chief cus-tomer care). 2) Kepala Departemen Teknik (chief engineering). 3) Kepala Depar-temen Tata Grha (chief housekeeping). 4) Kepala Depar-temen Administrasi dan Keuangan (chief finance \& administration). 5) Penyelia Teknik (engineer-ing supervisor). 6). Penyelia Tata Grha (house keeping supervisor). 7) Pekerja plambing (fitter). 8) Montir (mechanic). 9) Elektrikal (electrician). 
Kualitas pelayanan pemeliharaan adalah kemampuan organisasi untuk memenuhi atau mengatasi harapan penlanggan atau pengguna yang diterjemahkan sebagai keinginan dan ke-hendak pelanggan (Zeaithaml, 1990 dalam Azizah, 2008) dalam bukunya Delivaring Qua-lity Service, Balancing Customer Perpections and Expectations terdapat lima dimensi yang menjadi acuan pengukuran kualitas layanan pemeliharaan: 1) Tangibles yaitu aspek yang terlihat secara fisik penyedia jasa misalnya gedung pada komponen interior dan eksterior, fasilitas, peralatan, dan penampilan fisik dari personil pemberi layanan. 2) Reliability yaitu kemampuan untuk memiliki performa yang dapat diandalkan dan akurat. Kehandalan merupakan kemampuan dari penyedia jasa untuk mem-berikan service yang telah dijanjikan secara akurat, dapat dipercaya dan dapat diandalkan. Dengan kata lain, kehandalan berarti sejauh mana penyedia jasa mampu memberikan apa yang telah dijanjikan kepada konsumen. 3) Responsiveness yaitu kemauan, kesediaaan untuk merespon keinginan atau kebutuhan akan bantuan dari pelanggan serta pelayanan yang cepat. Hal ini merupakan kesediaan penyedia jasa terutama pegawainya untuk membantu konsumen serta memberikan pelayanan yang tepat sesuai kebutuhan konsumen. Dimensi ini lebih menekankan pada sikap dari penyedia jasa yang penuh perhatian, cepat, dan tepat dalam melayani permintaan, keluhan dan masalah yang dihadapi konsuman. 4) Assurance yaitu kemam-puan pada personil untuk menimbulkan rasa percaya dan aman serta menyakinkan kepada pelanggan. Jaminan atau assurance yaitu suatu dimensi yang menekankan kemampuan penyedia jasa untuk membangkitkan rasa percaya dan keyakinan diri konsumen bahwa pihak penyedia jasa terutama pegawainya mampu memenuhi kebutuhan konsumennya. 5) Empathy yaitu ke-mampuan personil untuk peduli dan memper-hatikan pada setiap pelanggan, yaitu merupakan kemampuan penyedia jasa dalam memperla-kukan pelanggan sebagai individu yang spesial.

\section{Metode Penelitian}

Populasi yang digunakan dalam peneli-tian ini adalah Sekolah Lanjutan Tingkat Atas (SLTA) di Kota Balikpapan yang berjumlah 15 (tujuh belas) sekolah. Namun SMA Negeri 9 tidak disertakan sabagai populasi karena SMA Negeri 9 belum memiliki gedung sendiri. Untuk populasi jumlah guru, pegawai, komite sekolah dan Pengurus inti OSIS (ketua, wakil ketua, sekretaris, bendahara, perwakilan kelas X, XI, XII) disajikan pada Tabel berikut:

Tabel 2: Jumlah Guru, Pegawai, Komite, Pengurus OSIS SLTA di Kota Balikpapan

\begin{tabular}{ccccccc}
\hline NO & $\begin{array}{c}\text { NAMA } \\
\text { SEKOLAH }\end{array}$ & $\begin{array}{c}\text { GU } \\
\text { RU }\end{array}$ & $\begin{array}{c}\text { PEGA } \\
\text { WAI }\end{array}$ & $\begin{array}{c}\text { KOMITE } \\
\text { SEKOLAH }\end{array}$ & $\begin{array}{c}\text { SIS } \\
\text { WA }\end{array}$ & $\begin{array}{c}\text { TO } \\
\text { TAL }\end{array}$ \\
\hline 1. & SMA Negeri 1 & 64 & 9 & 5 & 7 & 85 \\
2. & SMA Negeri 2 & 46 & 5 & 5 & 7 & 63 \\
3. & SMA Negeri 3 & 41 & 5 & 5 & 7 & 58 \\
4. & SMA Negeri 4 & 53 & 4 & 5 & 7 & 69 \\
5. & SMA Negeri 5 & 43 & 5 & 5 & 7 & 60 \\
6. & SMA Negeri 6 & 32 & 4 & 5 & 7 & 48 \\
7. & SMA Negeri 7 & 27 & 5 & 5 & 7 & 44 \\
8. & SMA Negeri 8 & 17 & 4 & 5 & 7 & 33 \\
9. & MA Negeri 1 & 28 & 4 & 5 & 7 & 44 \\
10. & SMK Negeri 1 & 109 & 5 & 5 & 7 & 126 \\
11. & SMK Negeri 2 & 58 & 5 & 5 & 7 & 75 \\
12. & SMK Negeri 3 & 58 & 7 & 5 & 7 & 77 \\
13. & SMK Negeri 4 & 46 & 4 & 5 & 7 & 62 \\
14. & SMK Negeri 5 & 32 & 4 & 5 & 7 & 48 \\
\hline & Jumlah & 654 & 70 & 70 & 98 & $\mathbf{8 9 2}$ \\
\hline
\end{tabular}

Sumber: Dinas Pendidikan Kota Balikpapan 2009

Untuk keperluan pengambilan data, yang dijadikan populasi berjumlah 892 orang ditambah dengan 6 orang pengawas SMA, 1 orang pengawas MAN, dan 4 orang pengawas SMK. Sehingga populasi seluruhnya berjumlah $892+6+1+4=903$ orang.

Teknik pengambilan sampel dalam pene-litian ini menggunakan proportionate stratified random sampling. Menurut Riduwan (2008) pro-portionate stratified random sampling ialah pengambilan sampel dari anggota populasi secara acak dan berstrata secara proporsional, dengan pertimbangan populasinya heterogen (tidak sejenis). Penentuan besar sampel diambil 
dengan menggunakan rumus dari Taro Yamane (Riduwan, 2008):

Dari rumus pengambilan sampel Taro Yamane (Riduwan, 2008) diperoleh jumlah sampel dengan nilai presisi $90 \%$ atau $d=$ $10 \%$ sebesar $=90,03$ orang. Dalam penelitian ini sampel diambil sebesar 100 orang lebih besar dari jumlah sampel minimal.

Untuk penyebaran sampel digunakan metode Random Bertingkat (Stratified Random Sampling) Disproporsional. Menurut Riduwan (2006) Random Bertingkat Disproporsional di lakukan dengan menyeleksi setiap unit sampling dengan ukuran yang tidak proposional terhadap ukuran unit sampling karena untuk kepentingan pertimbangan analisis dan kesesuaian. Cara ini dilakukan karena apabila diterapkan proporsi yang sebenarnya maka akan terjadi penge-lompokan sejumlah sampel pada unit sampel tertentu dan unit sampel yang lain tidak mendapatkan bagian (Tabel 3 kolom 4) oleh karena itu sampel ditentukan berdasarkan kesesuaian (disproporsional) seperti yang tertera pada Tabel 3 kolom 5.

Tabel 3: Penyebaran sampel

\begin{tabular}{|c|c|c|c|c|}
\hline NO & OBYEK & $\begin{array}{l}\text { POPU } \\
\text { LASI }\end{array}$ & $\begin{array}{c}\text { SAMPEL } \\
\text { PROPOR } \\
\text { SIONAL } \\
\text { (ORANG) }\end{array}$ & $\begin{array}{c}\text { SAMPEL } \\
\text { DISPRO } \\
\text { PORSIONAL } \\
\text { (ORANG) } \\
\end{array}$ \\
\hline 1. & $\begin{array}{l}\text { Kepala } \\
\text { Sekolah/Wa } \\
\text { kil Sarana } \\
\text { Prasarana }\end{array}$ & 14 & 1.55 & 14 \\
\hline 2. & Guru & 640 & 70.84 & 41 \\
\hline 3. & Pegawai & 70 & 7.75 & 14 \\
\hline 4. & $\begin{array}{l}\text { Komite } \\
\text { Sekolah }\end{array}$ & 70 & 7.75 & 14 \\
\hline 5. & Siswa & 98 & 10.85 & 14 \\
\hline 6. & $\begin{array}{l}\text { Pengawas } \\
\text { Sekolah }\end{array}$ & 11 & 1.26 & 3 \\
\hline & Jumlah & 903 & 100 & 100 \\
\hline
\end{tabular}

Sehingga dikeperlukan sampel untuk masing-masing sekolah adalah sebagai berikut:
Tabel 4: Penyebaran Sampel pada Sekolah

\begin{tabular}{cccccccc}
\hline NO & $\begin{array}{c}\text { NAMA } \\
\text { SEKOLAH }\end{array}$ & $\begin{array}{c}\text { KEP } \\
\text { SEK }\end{array}$ & $\begin{array}{c}\text { GU } \\
\text { RU }\end{array}$ & $\begin{array}{c}\text { PE } \\
\text { GA } \\
\text { WAI }\end{array}$ & $\begin{array}{c}\text { KOMITE } \\
\text { SEKO } \\
\text { LAH }\end{array}$ & $\begin{array}{c}\text { SIS } \\
\text { WA }\end{array}$ & $\begin{array}{c}\text { TO } \\
\text { TAL }\end{array}$ \\
\hline 1. & SMA Negeri 1 & 1 & 4 & 1 & 1 & 1 & $\mathbf{8}$ \\
2. & SMA Negeri 2 & 1 & 3 & 1 & 1 & 1 & $\mathbf{7}$ \\
3. & SMA Negeri 3 & 1 & 3 & 1 & 1 & 1 & $\mathbf{7}$ \\
4. & SMA Negeri 4 & 1 & 3 & 1 & 1 & 1 & $\mathbf{7}$ \\
5. & SMA Negeri 5 & 1 & 3 & 1 & 1 & 1 & $\mathbf{7}$ \\
6. & SMA Negeri 6 & 1 & 2 & 1 & 1 & 1 & 6 \\
7. & SMA Negeri 7 & 1 & 2 & 1 & 1 & 1 & $\mathbf{6}$ \\
8. & SMA Negeri 8 & 1 & 1 & 1 & 1 & 1 & $\mathbf{5}$ \\
9. & MA Negeri 1 & 1 & 2 & 1 & 1 & 1 & $\mathbf{6}$ \\
10. & SMK Negeri 1 & 1 & 7 & 1 & 1 & 1 & 11 \\
11. & SMK Negeri 2 & 1 & 3 & 1 & 1 & 1 & $\mathbf{7}$ \\
12. & SMK Negeri 3 & 1 & 3 & 1 & 1 & 1 & $\mathbf{7}$ \\
13. & SMK Negeri 4 & 1 & 3 & 1 & 1 & 1 & $\mathbf{7}$ \\
14. & SMK Negeri 5 & 1 & 2 & 1 & 1 & 1 & $\mathbf{6}$ \\
\hline & Jumlah & 14 & $\mathbf{4 1}$ & $\mathbf{1 4}$ & $\mathbf{1 4}$ & $\mathbf{1 4}$ & $\mathbf{9 7}$ \\
\hline
\end{tabular}

Jenis penelitian ini adalah survay dengan metode yang digunakan deskirptif analitis. Peneliti melakukan studi langsung kelapangan untuk melakukan pengamatan terhadap obyek yang dianalisa, dengan metode sebagai berikut: 1) Dokumentasi. 2) Wawancara dan Survey. 3) kuisioner.

Pengumpulan data yang dimaksudkan adalah pengumpulan data hasil investigasi lapangan yang berasal dari jawaban masukan balik kuesioner yang telah diedarkan kepada responden dan data lapangan dari dokumentasi pendukung hasil survay dan wawancara.

Data yang terkumpul sesuai variabel dan indikator penelitian, kemudian diolah dan dianalisa untuk mendapatkan faktor yang berpengaruhnya terhadap kualitas pemeliharaan guna memperta-hankan usia pakai bangunan gedung SLTA di Balikpapan.

Skala pengukuran yang digunakan dalam penelitian ini adalah Skala Likert dengan lima angka yaitu 5, 4, 3, 2, 1. Semua responden diminta untuk menjawab semua item pertanyaan, setelah kuesioner terkumpul maka dilakukan pemberian skor untuk setiap item jawaban. Selangkapnya sebagai berikut: Sangat Setuju $(\mathrm{SS})=5$, Setuju (S) = 4, Cukup Setuju (CS) = 3, Kurang Setuju $(\mathrm{KS})=2$, Tidak Setuju $(\mathrm{TS})=1$.

Variabel yang dianalisis dalam penelitian ini dibedakan menjadi variabel bebas (inde-penden) dan variabel terikat (dependen). 1) Variabel bebas (X) merupakan variabel yang mempengaruhi 
atau yang menjadi sebab perubahannya atau timbulnya variabel terikat (Sugiyono, 2008). Variabel bebas yang akan mempengaruhi variabel terikat terdiri dari: a) Variabel Komponen Arsitektur $\left(\mathrm{X}_{1}\right)$. b) Variabel Komponen Struktur $\left(\mathrm{X}_{1}\right)$. c) Variabel Komponen Utilitas $\left(\mathrm{X}_{1}\right)$. 2) Variabel terikat (Y) adalah variabel yang dipengaruhi atau yang menjadi akibat karena adanya variabel bebas (Sugiyono, 2008). Dalam penelitian ini variabel terikat (dependen) adalah kualitas pemeliharaan bangunan gedung SLTA dengan menggunakan pendekatan lima dimensi pendapat Zeaithaml, 1990 dalam Azizah, 2008.

Untuk menghindari perbedaan inter-pretasi atas istilah serta variabel yang digunakan dalam penelitian ini, maka perlu dikemukakan definisi operasional sebagai berikut: a) Peme-liharaan komponen arsitektur $\left(\mathrm{X}_{1}\right)$ adalah peme-liharaan komponen fisik bangunan yang terdiri dari: atap, dinding, lantai, pintu dan jendela, plafond, dan jadwal serta intensitas pemeliharaannya. Pada variabel ini yang optimalkan adalah estetika visual dan dampak kenyamanan yang di akibatkkan. b) Pemeliharaan komponen struktur $\left(\mathrm{X}_{2}\right)$ adalah merupakan pemeliharaan komponen bangunan terkait dengan kekokohan dan kestabilan struktur bangunan, sehingga aman dan stabil terhadap semua beban bangunan yang ada. Variabel ini terdiri dari: pondasi, kolom, balok dan jadwal serta intensitas pemeliharaannya. c) Pemeliharaan komponen utilitas $\left(\mathrm{X}_{3}\right)$ adalah pemeliharaan komponen penunjang dalam maupun luar bangunan yang terdiri dari: elektrikal dan penerangan, instalasi air bersih, instalasi air kotor, fasilitas pemadam kebakaran, Jaringan Air Conditioner (AC), fasilitas komu-nikasi, jaringan komputer, dan jadwal serta intensitas pemeliharaannya. d) Kualitas peme-liharaan (Y) adalah hasil akhir dari obyek pemeliharaan komponen bangunan yang terdiri dari tiga komponen seperti tersebut di atas yang ditinjau menggunakan prinsip lima dimensi (Zeaithaml, 1990 dalam Azizah, 2008).

Metode pengolahan data menggunakan Analisis Jalur (path analysis) yang dikembang-kan sebagai metode untuk mempelajari pengaruh (efek) secara langsung dan tidak langsung dari variabel bebas terhadap variabel terikat. Analisis ini merupakan salah satu pilihan dalam rangka mempelajari ketergantungan sejumlah variabel di dalam model, analisis ini digunakan untuk menelaah hubungan antara model kausal yang telah dirumuskan peneliti atas dasar pertimbangan teoritis dan pengetahuan tertentu. Hubungan kausal selain didasarkan pada data, juga didasarkan pada pengetahuan, perumusan hipotesis dan analisis logis secara kausal serta untuk menafsirkan pola hubungan tersebut.

Analisis jalur bukanlah untuk menemu-kan penyebabnya, melainkan suatu metode untuk menelaah hubungan antar variabel pada model kausal yang telah dirumuskan peneliti atas dasar pertimbangan teoritis dan pengetahuan tertentu. Analisis Jalur merupakan pengembangan dari analisis regresi, sehingga analisis regresi dapat dikatakan sebagai bentuk khusus dari analisis jalur. Analisis jalur digunakan untuk melukiskan dan menguji model hubungan antar variabel yang berbentuk sebab akibat (Bachrudin Achmad dan Tobing L. Harapan, 2003) dengan tujuan untuk menentukan pengaruh langsung dan tidak langsung antara sejumlah variabel bebas terhadap variabel terikat.

\section{Hasil dan Pembahasan}

Hasil survey dan kuisioner menunjukkan bahwa bangunan gedung SLTA di Balikpapan rata-rata sudah berusia di atas 10 tahun, dan manajemen pemeliharaan gedung yang telah dan sedang diterapkan oleh manajemen sekolah secara garis besar dapat dikelompokkan menjadi 3 model pemeliharaan: 
a. Manajemen Pemeliharaan Gedung Model I

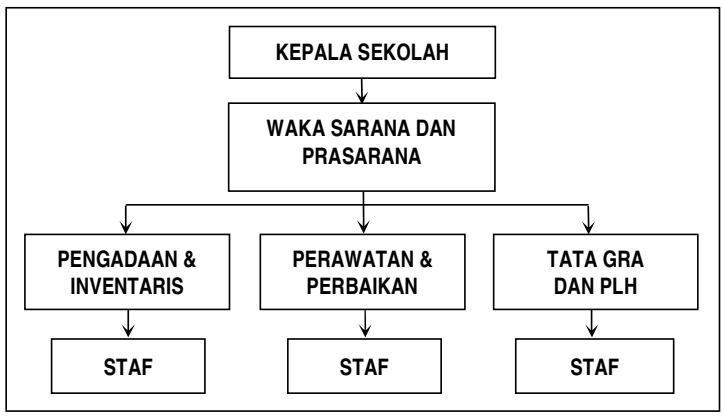

Gambar 2: Struktur organisasi pemeliharaan gedung model I

Rencana pemeliharaan di sulkan secara tertulias oleh kepala satuan kerja kepada Kepala Sekolah melewati Waka Sarana Prasarana, disetujui oleh manajemen sekolah dan di laksanakan oleh Waka Sarana Prasarana.

\section{b. Manajemen Pemeliharaan Gedung Model II}

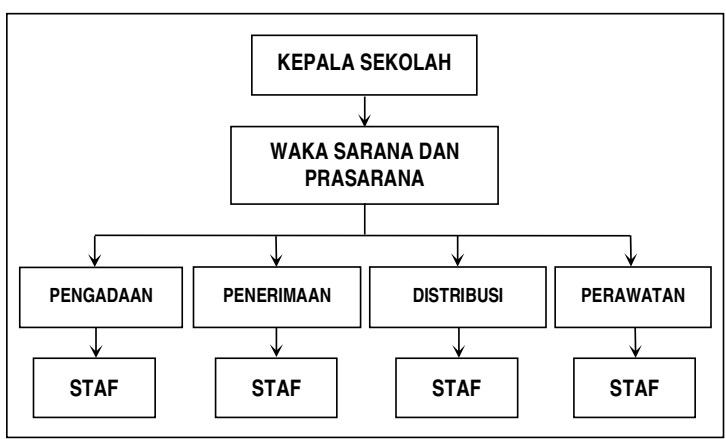

Gambar 3: Struktur organisasi pemeliharaan gedung model II

Recana pemeliharaan di usulkan secara tertulis oleh kepala satuan kerja kepada melewati Waka Sarana Prasarana, disetujui oleh mana-jemen sekolah dan dilaksnakan oleh satuan kerja.

\section{c. Manajemen Pemeliharaan Gedung Model III}

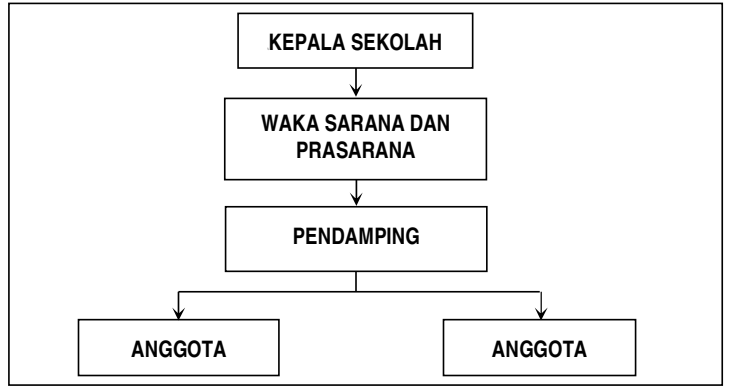

Gambar 4: Struktur organisasi pemeliharaan gedung model III
Rencana pemeliharan di usulkan secara tertulias oleh kepala satuan kerja kepada Keepala Sekolah, dan disetujui oleh Kepala Sekolah, dilaksanakan oleh kepala satuan kerja.

Dari hasil analisis deskriptif dapat disim-pulkan bahwa komponen pemeliharaan gedung SLTA di Kota Balikpapan yang paling ber-pengaruh terhadap kualitas pemeliharaan bangunan gedung berturut-turut adalah Komponen Arsitektur ( $\left.\mathrm{X}_{1}\right)$ sebesar $94.40 \%$ tingkat pengaruh sangat kuat, Komponen Utilitas $\left(\mathrm{X}_{3}\right)$ sebesar $85.60 \%$ tingkat pengaruh sangat kuat, dan Komponen Struktur $\left(\mathrm{X}_{2}\right)$ sebesar $85.20 \%$ tingkat pengaruh sangat kuat. Selengkapnya lihat tabel berikut:

Tabel 5: Ranking Tingkat Pengaruh Variabel Bebas (X) Terhadap Variabel Terikat (Y)

\begin{tabular}{clcc}
\hline $\begin{array}{c}\text { Ran } \\
\text { king }\end{array}$ & \multicolumn{1}{c}{ Variabel } & $\begin{array}{c}\text { Nilai TP } \\
(\%)\end{array}$ & $\begin{array}{c}\text { Tingkat } \\
\text { Pengaruh }\end{array}$ \\
\hline 1 & $\begin{array}{l}\text { Pemeliharaan } \\
\text { Komponen Arsitektur } \\
\left(\mathrm{X}_{1}\right)\end{array}$ & $94.40 \%$ & $\begin{array}{c}\text { Sangat } \\
\text { Kuat }\end{array}$ \\
2 & $\begin{array}{l}\text { Pemeliharaan } \\
\text { Komponen Utilitas }\left(\mathrm{X}_{3}\right)\end{array}$ & $85.60 \%$ & $\begin{array}{c}\text { Sangat } \\
\text { Kuat }\end{array}$ \\
& $\begin{array}{l}\text { Pemeliharaan } \\
\text { Komponen Struktur } \\
\left(\mathrm{X}_{2}\right)\end{array}$ & $85.20 \%$ & $\begin{array}{c}\text { Sangat } \\
\text { Kuat }\end{array}$ \\
\hline
\end{tabular}

Dalam penelitian ini analisis jalur diper-gunakan untuk mengetahui pengaruh langsung dan tidak langsung variabel bebas pemeliharaan komponen arsitektur $\left(\mathrm{X}_{1}\right)$, komponen struktur $\left(\mathrm{X}_{2}\right)$, dan komponen utilitas $\left(\mathrm{X}_{3}\right)$ terhadap kualitas pemeliharaan bangunan gedung SLTA di Kota Balikpapan (Y).

Dari analisis jalur diperoleh koefisien $\mathrm{X}_{1}, \mathrm{X}_{2}$, dan $\mathrm{X}_{3}$ sebagai berikut:

$$
Y=0.556 X_{1}+0.339 X_{2}+0.783 X_{3}
$$

- Y dipengaruhi $0.556 \mathrm{X}_{1}$ (Pemeliharaan Komponen Arsitektur)

- Y dipengaruhi $0.339 \mathrm{X}_{2}$ (Pemeliharaan Komponen Struktur)

- Y dipengaruhi $0.783 \mathrm{X}_{3}$ (Pemeliharaan Komponen Utilitas) 
Hasil korelasi antar variabel bebas adalah:

Tabel 6: Matrix Korelasi antar Variabel Bebas $\left(\mathrm{R}_{123}\right)$

\begin{tabular}{ccccc}
\hline & $\mathbf{X}_{\mathbf{1}}$ & $\mathbf{X}_{\mathbf{2}}$ & $\mathbf{X}_{\mathbf{3}}$ & $\mathbf{Y}$ \\
\hline $\mathbf{X}_{\mathbf{1}}$ & 1 & .222 & -.008 & .625 \\
$\mathbf{X}_{\mathbf{2}}$ & .222 & 1 & -.216 & .293 \\
$\mathbf{X}_{\mathbf{3}}$ & -.008 & -.216 & 1 & .705 \\
$\mathbf{Y}$ & .625 & .293 & .705 & 1 \\
\hline
\end{tabular}

Dengan faktor Sisaan $\boldsymbol{\varepsilon}$ (residual): $\rho_{\mathrm{Y} \varepsilon}=$ 0.039 , Sehingga dari hasil analisis tersebut diagram jalur dan nilai koefisiennya sebagai berikut:

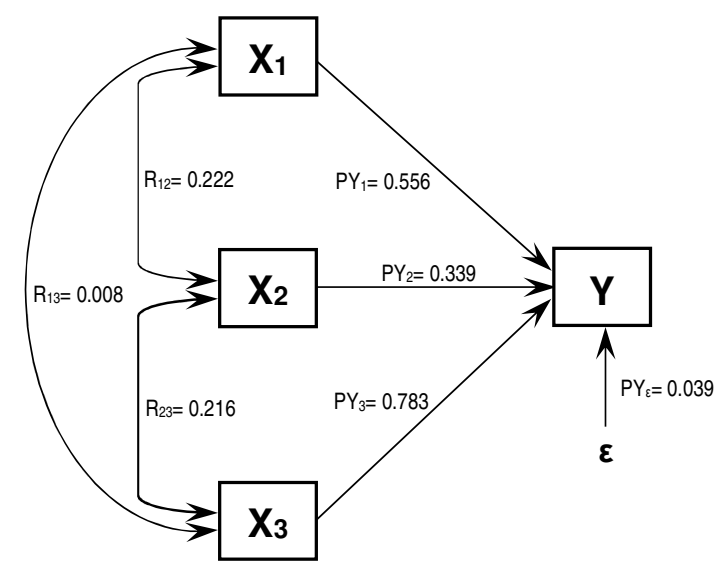

Gambar 5: Diagram jalur

Sehingga persamaan jalurnya menjadi:

$Y=0.556 X_{1}+0.339 X_{2}+0.783 X_{3}+0.039$

$\varepsilon$

Penjumlahan angka koefisien jalur sebesar 1.717. setelah jumlah persamaannya dibuat $=$ 1 (satu), diperoleh koefesien akhir sebagai berikut:

Tabel 7: Koefisien Jalur Variabel $\mathrm{X}_{1}, \mathrm{X}_{2}, \mathrm{X}_{3}$ secara simultan terhadap variabel $\mathrm{Y}$ setelah dilakukan koreksi atas persamaan jalur

\begin{tabular}{ccccc}
\hline Variabel & $\begin{array}{c}\text { Koefisi- } \\
\text { en Jalur }\end{array}$ & $\begin{array}{c}\text { Kontribusi } \\
\text { Langsung }\end{array}$ & $\begin{array}{c}\text { Kontribusi } \\
\text { Secara } \\
\text { Simultan }\end{array}$ & $\begin{array}{c}\text { Kriteria } \\
\text { Pengaruh }\end{array}$ \\
\hline $\mathbf{X}_{1}$ & .324 & $32.40 \%$ & - & $\begin{array}{c}\text { Rendah } \\
\text { Sangat } \\
\mathbf{X}_{2}\end{array}$ \\
$\mathbf{X}_{3}$ & .197 & $19.73 \%$ & - & $\begin{array}{c}\text { Rendah } \\
\text { Cukup } \\
\text { Kuat }\end{array}$ \\
$\varepsilon$ & .0023 & $2.27 \%$ & - & $\begin{array}{c}\text { Sangat } \\
\text { Rendah } \\
\text { Sangat } \\
\text { Kuat }\end{array}$ \\
$\mathbf{X}_{1}, \mathbf{X}_{2}, \mathbf{X}_{3}$ & - & - & $97.73 \%$ & \\
\hline
\end{tabular}

\section{Kesimpulan dan Saran}

Berdasarkan hasil penelitian dan pembahasan, maka dapat ditarik kesimpulan sebagai berikut: 1) Manajemen pemeliharaan ge-dung SLTA yang terdapat di Balikpapan pada saat ini dapat di kelompokkan menjadi 3 model, yaitu: a) Model I. Rencana pemeliharaan di usulkan secara tertulis oleh Kepala Satuan Kerja kepada Kepala Sekolah melewati Waka Sarana Prasarana, disetujui oleh Manajemem Sekolah dan dilak-sanakan oleh Waka Sarana Prasarana. b) Model II. Rencana pemeliharaan di usulkan secara tertulis oleh Kepala Satuan Kerja kepada Kepala Sekolah melewati Waka Sarana Prasarana, disetujui oleh Manajemen Sekolah dan dilaksanakan oleh Satuan Kerja. c) Moedl III. Rencana pemeliharaan diusulkan secara tertulis oleh Kepala Satuan Kerja langsung kepada Kepala Sekolah, disetujui oleh Kepala Sekolah dan dilaksanakan oleh Satuan Kerja. Dari ketiga model tersebut, hasil survey menunjukkan bahwa model I tampilan gedung secara visual lebih baik dibandingkan model lainnya. 2) Besarnya pengaruh pemeliharaan komponen bangunan gedung SLTA di Balikpapan secara parsial secara analisis deskriptif adalah sebagai berikut: a) Pemeliharaan Komponen Arsitektur secara parsial memberikan pengaruh terhadap Kualitas Pemeliharaan Bangunan Gedung terbesar pertama yaitu sebesar $94.40 \%$ dengan tingkat pengaruh sangat kuat. b) Pemeliharaan Komponen Utilitas secara parsial memberikan pengaruh terhadap Kualitas Pemeliharaan Gedung terbesar kedua yaitu sebesar $85.60 \%$ dengan tingkat pengaruh sangat kuat. c) Pemeliharaan Komponen Struktur secara parsial memberikan pengaruh ter-hadap Kualitas Pemeliharaan Bangunan Gedung terbesar ketiga yaitu sebesar $85.20 \%$ dengan tingkat pengaruh sangat kuat. 3) Besarnya pengaruh pemeliharaan komponen bangunan gedung SLTA di Balikpapan secara simultan menggunakan analisis Jalur (Path Analysys) terhadap kualitas pemeliharaan bangunan gedung adalah sebagai berikut: Secara simultan pemeli-haraan komponen asritektur $\left(\mathrm{X}_{1}\right)$, komponen struktur $\left(\mathrm{X}_{2}\right)$, dan komponen utilitas $\left(\mathrm{X}_{3}\right)$ dengan nilai koefisien total sebesar $97.73 \%$, dengan nilai 
$\rho$ terbesar adalah Sig. $0.03<0.05$ dan kriteria tingkat pengaruh sangat kuat, berarti berpengaruh dan signifikan terhadap kualitas peme-liharaan gedung SLTA di Balikpapan. Saran. Berdasarkan temuan hasil penelitian ini maka dikemukakan saran-saran sebagai berikut: 1) Manajemen pemeliharaan gedung model I secara tampilan visual bangunan gedung hasilnya lebih baik dibandingkan dengan model lainnya. Untuk itu manajemen sekolah di Balikpapan pada umumnya dan manajemen sekolah SLTA khu-susnya dapat merujuk model I untuk dijadikan acuan dan referensi guna meningkatkan kualitas pemeliharaan gedung sekolah. 2) Kepada para peneliti untuk melakukan penelitian lanjutan guna mengkaji dan menggali lebih dalam mengenai kualitas pemeliharaan gedung sekolah di Balikpapan secara menyeluruh, supaya populasi penelitian ditingkatkan mencangkup SD, SLTP, SLTA dan menambahkan variabel yang belum di bahas dalam penelitian ini.

\section{Daftar Pustaka}

Achmad Bacrudin, L. Tobing. 2003. Analisis Data untuk Penelitian Survai dengan menggunakan Lisrel 8, Jurusan StatistkaUnpad. Bandung.

Azizah Abdul Rahman, Rose Alinda Alias. Servqual Dalam Penelitian Kualitatif Se-rvis sistem Maklumat, University Tech-nologi Malaysia, 81310 Skundai. Johor.

Bungin Burhan. 2004. Metodologi Penelitian Kuantitatif, Fajar Interpratama Offset. Jakarta.

Corder Antony, Kusnul Hadi. 1996. Teknik Manajemen Pemiliharaan, Cetakan III. Erlangga Jakarta.

Departemenf Public Work. 2001. Maintenance Management Framework. Australia.

Friady Wahyu, 2009. Faktor-faktor yang Mem-pengaruhi Keterlambatan Proyek Konstruksi, Jurnal Program Studi Teknik Sipil Pascasarjana Universitas Brawi-jaya. Malang.

Heintzelman, E. John. 1976. The Complete Handbooks of Maintenance Manage-ment,
New York: Prentice-Hall Inc. Englewood Cliffs.

Hinggins Lindley, R.P.E. 2002. Maintenance Engineering Handbooks, New York. Mc.Draw-Hill Standard Handbook.

Horner. R.M.W. $1997 . \quad B u i l d i n g$ Maintenance Strategy : A New Management Approach. Dundee - Scotland.

Hudson W. Ronald. 1997. Infrastructure Mana-gement, New York: Mc. Graw-Hill.

Kepmen Kimpraswil. Nomor 332 Tahun 2002 tentang Pedoman Teknis Pembangunan Bangunan Gedung Negara, PT. Media-tama Saptakarya. Jakarta.

Kodoatie, J, Robert. 2005. Pengantar Manaje-men Infrastruktur, Pustaka Pelajar. Yogyakarta.

Maintenance Management System, Technical Informatian Document, dsp-psd. pwgsc. gc.ca. 12 Pebruari 2008.

Mann Lawrence, Jr. 1985. Maintenance Management, Third Printing Lexing-tonBooks. Toronto.

Marsudi Joyowiyono. 1995. Perawaratan Bangunan Gedung di Indonesia, PT. Ideco Utama. Jakarta.

Miles Derek. 2000. Building Maintenance; A Management Manual, Intermadiate Technology Publications. London.

NASA. 2003. The NASA Deffered Maintenance Parametric estimating Guide, Version 2, California. USA.

Riduan. 2007. Metode dan Teknik Menyusun Tesis, CV. Alfabeta. Bandung.

Riduwan, Drs. MBA, Kuncoro Engkus Achmad, Dr. SE, MM. 2008. Cara Menggunakan dan Memakai Analisis Jalur (Path Analysis). Alfabeta. Bandung.

Santoso. B dan Ashari. 2005. Analisis Statistik dengan Microsoft Excel dan SPSS, Penerbit Andi. Yogyakarta.

Santoso, Singgih. 2009. Menguasai Statistik dengan SPSS 17. Elex Media Kompu-tindo. Jakarta.

Satriono dan Rita H. 2007. Filsafat Ilmu dan Metodologi Penelitian, Penerbit Andi. Jakarta.

Sedayu Agung, 2009. Manajemen Pemeliharaan Infrastruktur dalam Pengelo-laan GOR Ken Arok Malang, Jurnal Program Studi Teknik Sipil Pascasar-jana Universitas Brawijaya. Malang.

Siregar D. Doli. 2004. Manajemen Aset, PT. Gramedia Pustaka Utama. Jakarta. 
Solimun. 2002. Structural Equation Modeling Lisrel dan Amos, Penerbit Universitas Negeri Malang. Malang.

Sugiyono, Prof. Dr. 2009. Statistika untuk

Penelitian.Alfabeta. Bandung

Suharjo, Bambang. 2008. Analisis Regresi Terapan dengan SPSS, Graha Ilmu. Yogyakarta.

Supangat Andi. 2007. Statistika Dalam Kajian Deskruptif Inferensi, dan Nonparame-trik, Prenada Media Grup. Jakarta.

Tanggoro, Dwi. 2000. Utilitas Bangunan. Jakarta. Universitas Indonesia Press

The REMR. 1996. Condition Index : Condi-tion Assessment for Mainte-nance, REMR, Technical Note, OM-Ci-1.2.

US Department of Education. 2003. Planning Guide for Maintaining School Facilities, National Center for Educa-tion Statistics Institute of Education Sciences. Washington.DC.

Wahyono, Teguh. 2009. Model Analisis Statistik dengan SPSS 17. Elex Media Kompu-tindo. Jakarta.
Wardjoyo Djoko. 2008. Analisa "Overruns" Biaya Perubahan Pelaksanaan Peker-jaan Proyek Rehabilitasi Gedung P4TK/ VEDC Malang, Jurnal Program Studi Teknik Sipil Pascasarjana Universitas Brawijaya. Malang.

Peraturan Menteri Pendidikan Nasio nal Nomor 19 Tahun 2003 tentang Standar

Nasional Pendidikan.

......., Peraturan Menteri Pekerjaan Umum Nomor 20 Tahun 2006 tentang Pedoman Persyaratan Teknis Bangunan Gedung.

......., Peraturan Menteri Pekerjaan Umum Nomor 24 Tahun 2008 tentang Pedoman Pemeliharaan dan Perawatan Bangunan Gedung.

......., Undang - Undang Republik Indonesia Nomor 28 Tahun 2002 tentang

Bangunan Gedung.

........, Undang - Unadng Republik Indonesia Nomor 20 Tahun 2003 tentang Sistem Pendidikan Nasional.

http://www.kompas.com/2009/11/19

http://www.mediaindonesia.com/2008/11/20

http://www.tempointeraktif.com/2008/05 